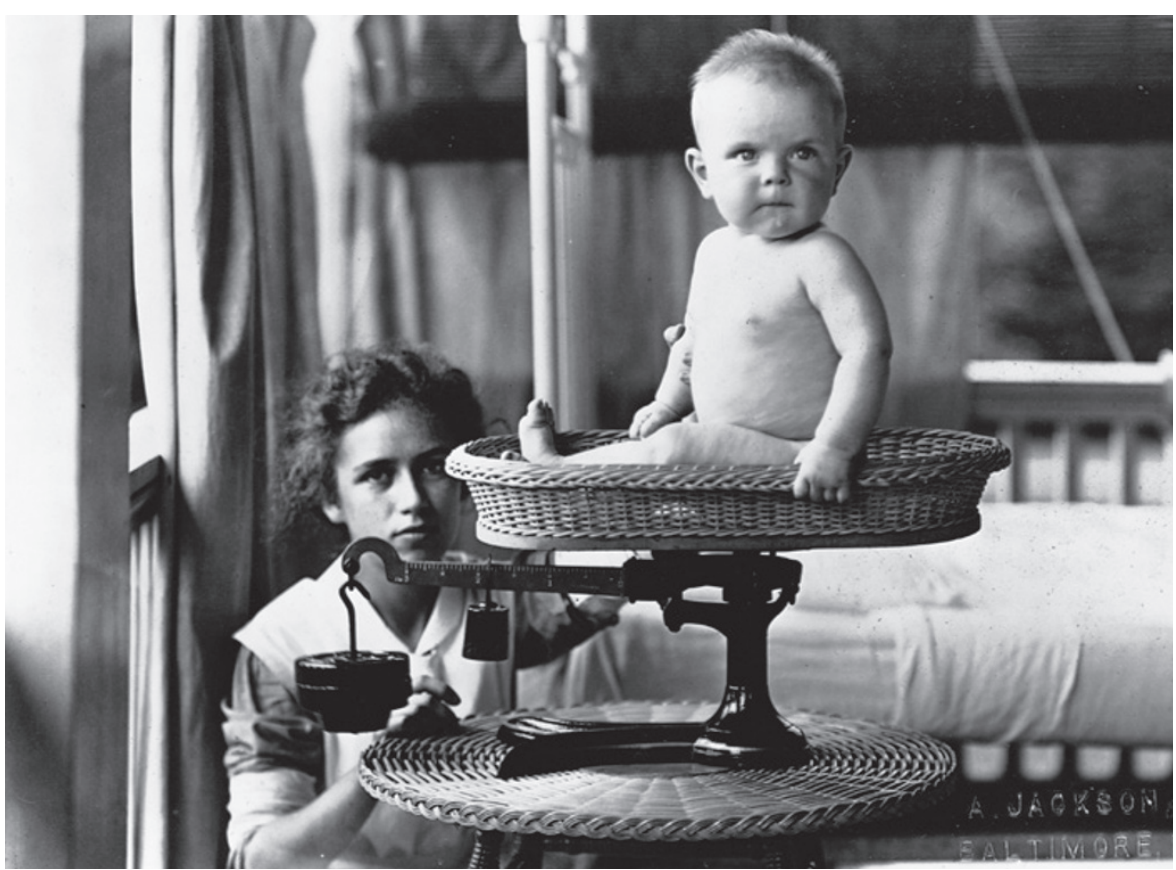

Standards for children's weight began to be established at the turn of the twentieth century.

\title{
HEALTH
}

\section{The medicalization of fat}

\section{A history of the shifts in US society's view of the larger child grips David Katz.}

$\mathrm{B}$ etween the moment I began to read Laura Dawes's Childhood Obesity in America and my completion of this review, two high-profile studies came out on US childhood obesity. The first suggested a slight decline in obesity rates among 2-5 year olds, spawning headlines claiming that overall childhood-obesity rates had plummeted (C. L. Ogden et al. J. Am. Med. Assoc. 311, $806-814 ; 2014)$. The second reported that severe obesity in children aged 2-19 was rising (A. C. Skinner and J. A. Skelton J. Am. Med. Assoc. Pediatr. http://doi.org/svw; 2014).

Such wild gyrations say something about our emotionally charged relationship with this topic. However intense the preoccupation with childhood obesity, it is not an exclusively modern phenomenon. What differ are the medical, cultural and moral lenses through which we view it, and its salience in modern epidemiology. Dawes acknowledges that much of the prevailing attention to childhood obesity is "a lament of modernity", and she has 100 years of carefully collated evidence to prove it. Through anecdotes and an overview of social trends, she provides the historical context for our fixation, revealing shifting cultural perceptions, medical preoccupations, scientific advances and economic forces linked to the phenomenon. By clarifying where we have been, Dawes aims to guide us forward.

Adiposity has at times been admired. In Renaissance Europe, it was synonymous with wealth; in the Baroque period it was an attribute of feminine beauty. And it was valued in the United States around the start of the twentieth century, as Dawes shows. Charley Bilcher, for instance,

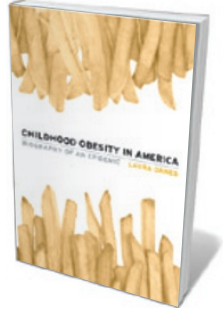

Childhood Obesity in America: Biography of an Epidemic LAURA DAWES Harvard University Press: 2014. was a Pennsylvanian boy whose bulk was a source of pride to his parents - and to the nation when, in 1896, he won the title of "fattest boy in the world".

As Dawes shows, when the extra-large child was rare, she or (mostly) he was likely to be acclaimed. With nearly one-fifth of US children and adolescents now obese, the tide of opinion has turned. A tendency to appreciate bulk may have origins in the evolutionary struggle to ensure that children had enough to eat. Around the time of Bilcher's win, the girth of US-born versus immigrant children was a national preoccupation. "Better Babies" contests became popular, fuelled in part by the "more abundant comforts" proffered by US industry. By showing how recently such a stance prevailed, Dawes shines a light on an important source of cultural ambivalence about the 'war' on obesity. Maybe we are yet to win because we are fighting with half a heart.

Dawes shows how much time and effort in the early twentieth century was devoted to generating measures of obesity that we take for granted today. A focus on length and weight standards was established with physician Luther Emmet Holt's 1894 The Care and Feeding of Children, and measures such as the Ponderal index - precursors to the body mass index - emerged. The more reliably obesity could be measured, the more it mattered: measuring informs norms; norms are used for comparison; and comparisons illuminate outliers. Dawes traces the emergence of paediatrics as a medical speciality in the 1870 s, advances in epidemiology such as the capture of population-level data to establish reference standards for height and weight, and a growing respect for objective measures.

To me, the most fascinating portion is the chronological sequence of ideas about the causes and cures of childhood obesity, because they reveal how often we have gone back to the future. In Diet and Health (1918), the first best-selling US diet book, physician Lulu Hunt Peters aired the idea of the calorie as a factor in obesity. The glandular theory of obesity was a prominent paradigm into the 1940s: a 1937 case series showed that eight obese children had been successfully treated with pituitary-gland extracts and thyroid tablets. Today, debate still simmers about the importance of the endocrine system in obesity, with some arguing that hormonal imbalance explains the condition so well that calories cease to matter. Dawes's chronology also shows how there has been a focus on one cause or remedy to the exclusion of others. When 'glands' were to blame, psychology was largely ignored. When psychoanalysts held sway, endocrinologists were pushed aside. In Dawes's final chapters, she hints at a potential solution through a synthesis of such ideas.

Dawes is neither a clinician nor a publichealth practitioner; she is a historian of medicine. But perhaps health professionals' efforts to contain, control, prevent and reverse childhood obesity have been constrained by a failure to see and consider the full scope of the threat and the best defences - that is, by the focus on one idea at a time. Dawes replaces such parochial perspectives with a window 100 years wide. May it help show us the way.

David Katz is the founding director of Yale University Prevention Research Center in Derby, Connecticut, and editor-in-chief of Childhood Obesity. His latest book is Disease Proof. e-mail:david.katz@yale.edu 